\title{
English Garden Master William Gould's Activity in the South of Russia
}

\author{
Vladimir Chekmarev ${ }^{1, *}$ \\ ${ }^{1}$ Scientific Research Institute of Theory and History of Architecture and Town Planning, Branch of the Federal \\ State Budget Institution "Central Scientific-Research and Project Institute of the Construction Ministry of \\ Russia", Moscow, Russia \\ "Corresponding author. Email: wchekmarev@yandex.ru
}

\begin{abstract}
The article concerns William Gould's landscape parks created for Prince G.A. Potemkin in the south of Russia in the late 1770s-1780s. The method of research is based on the study of archives and bibliography. The relevance of the article is due to insufficient consideration of the stated topic in the special literature.
\end{abstract}

Keywords: Landscape gardening, Southern regions of European Russia, The work of William Gould, Prince G.A. Potemkin.

\section{INTRODUCTION}

Among the greatest masters of domestic landscape gardening a native of the north-west of England (Ormskirk, Lancashire) William Gould (1735 - 1812) should be mentioned. Gould was one of the most talented students of L. Brown and also like his teacher had a rare talent for comprehensive analysis of the terrain for which, in fact, he was nicknamed «Russian Capability». [16 $]^{\text {p.82 }} \mathrm{He}$ fully mastered the artistic method of Brown and could widely use it in the formation of a variety of landscape compositions. From the 1794 Application of an English gardener for a grant, it becomes known that Gould arrived in the service of G.A. Potemkin in 1776. [1]

Since the beginning of the 1780s, the circle of his professional activity will expand many times. New Russia, Little Russia, and Belarus, where the Potemkin estate complexes were no less active, will be added to the work already underway in the St. Petersburg and Moscow regions. In fact, since that time, Gould has been constantly on the move, returning to the capital each time and leaving it again. In essence, this activity was an integral part of the already begun large-scale development of the

*Fund: This study is based on the research, supported by the Program of Fundamental Research of the Russian Academy of Architecture and Construction Sciences and of the Ministry of Construction, Housing and Utilities of the Russian Federation 2021. new lands that became part of the empire. Potemkin parks will be created by Gould in Kremenchug, Kherson, Nikolaev, Bogoyavlensk, the capital of Novorossiya Ekaterinoslav.

\section{WILLIAM GOULD AS PRINCE G.A.POTEMKIN'S GARDERNER}

After getting acquainted with the Crimea and appreciating its natural beauty and enormous economic potential, Gould will send Potemkin a number of letters containing specific proposals for the development of both steppe and foothill, as well as its coastal areas. [2] The prince will also instruct him to arrange «instant gardens», including in the places of stops Catherine II traveling on the Crimean land in 1787. Being, in fact, the largest owner of the Crimean estates, Potemkin will order to start «English gardens» in Simferopol, Kach, Alupka, Karasu-Bazar, Burunche, in Bidar located in the Baydar Valley. For him, Gould will form parks in the former center of the Zaporozhye Sich, Little Russian Khortytsia, as well as in the Belarusian Dubrovna, which the prince inherited from the voivode A. Sapieha, where once again the gardener will work together with I.E. Starov. [3]

Probably, Gould will develop his first design idea for southern Russia in the late 1770s. Obviously, it was a complex reconstruction of the regular park located here in an old estate. The 
Russian State Military-Historical Archive has preserved the documents of G.A. Potemkin, including those related to the improvement of the island of Khortytsia - «The plan of the garden on the Khortytsia Island of His Serene Highness Prince Grigory Alexandrovich Potemkin with an indication of different structures on it» and «The plan of the Khortytsia Island taken on the Dnieper River with an indication of different forests, meadows, winter gardens and other situations». [4]

According to the general plan, the landscape park Gould will plan on the vast coastal territory of the New Dnieper, which stretched from the northwest to the south-east. It was intersected by four long ravines that approached directly to the Dnieper, which further diversified the heavily rugged terrain and made it possible to significantly enhance its purely picturesque perception. Judging by the presence of projected park buildings, Gould in this case was guided mainly by the garden ideas of W. Chambers. So, the various landscape parts had to include organically a number of artistically significant buildings - a Turkish house, Chinese, Gothic, Greek, Ionic, Tuscan and Doric temples, an Egyptian pyramid, stone mountains and even a pagoda. Accordingly, in addition to the asymmetric network of walking paths, it was planned to build numerous bridges through the ravines, whose location also had to emphasize the perception of these buildings and the landscape associated with them in every possible way.

In 1781 - 1782, going from St. Petersburg to Kherson, Academician V. Zuev will also visit the island of Khortytsia, «on which Prince Potemkin makes special efforts for breeding and decoration». Consequently, at this time, the formation of the «English garden» was still going on. The remains of this park were preserved several decades later. So, one of the travelers of the beginning of the XIX century noticed: «On the southern tip of the island, they show a garden, calling it Potemkin, which was supposedly planted by the will of the magnificent Prince of Taurida. The place chosen by him is in many respects excellent (...) the surface of the island is not rocky and sandy, but steppe, which is a convenient plain». [5]

Gould will set up his next park in Kherson in 1784 - 1785 between the fortress and the newly created Merchant Forstadt. This time it had a very regular layout structure, being located on 14 acres of land, «along which the post road from the pier to the city of Nikolaev later passed». [6]
Probably also the first half of the 1780s should be attributed to the construction of the Gould park in Kremenchug, which was at that time the center of Novorossiya. It was located on the bank of the Dnieper. After visiting it in 1787 Catherine II emphasized: «I spent three days in a large, beautiful and charming house built by Field Marshal Prince Potemkin near a beautiful oak grove and a garden in which there are pear trees of such height as I have never seen in my life». [7] Soon after the death of the prince, this «English garden» was allowed for public use. So, in 1792, an unknown traveler in this connection noted: «The inhabitants walk along the pond, which lies outside the city, at a large beautiful gate, and is lined with trees on all sides; here and there you can see alleys and small groves, and we were pleased to note how art can turn into pleasant and even beautiful alleys always sandy and swampy places». [8]

Having found himself on May 3, 1785, already in the Crimean Karasubazar, Gould, in a letter to G.A. Potemkin, in particular, writes: «Passing from Kremenchug to Perekop, and from there to KarasuBazar through the most fertile land, I did not see any trees on it, I dare suggest to Your Grace that it would be very useful to plant various trees, and in some places mulberries. If Your Lordship finds this proposition agreeable, I could recommend to him a very skilful man from the province of York, who could agree to three or four hundred rubles a year. However, for such a space of land, one person is not enough». [9] It was here, in accordance with the order of Potemkin dated March 6, 1787, to the general-in-chief V.V. Kakhovsky, that Gould was entrusted with the construction of a landscape park at the Travel Palace already built here - «on the use of the English gardener Gould sent to Tavrida to decorate the garden at the house of Karasubasarsky». [10] The fact that it was formed in the shortest possible time is confirmed by the French Count Segur, who accompanied Catherine II during a trip to the Crimea, who wrote in his diary: «(here) ...the prince had a beautiful palace surrounded by a garden with fountains and an artificial waterfall. The garden, illuminated in a magnificent way, surprised everyone with its beauty». [11] This vast «English garden», thanks to the involvement of soldiers, was created on the banks of the picturesque Karasu River and was an integral part of the Potemkin estate complex. In fact, then in Karasubazar, a grand salute was arranged in honor of the empress, who «came out of the palace to enjoy the cool shade, the freshness of the water and the smell of flowers». [12] 
And on April 2, 1785 Potemkin will give another order to V.V. Kakhovsky in connection with the next proposal of his gardener: «Following Gould's advice, plant a paradise tree (poplar) on the Kacha River in wet places, and in the fall try to get a lot of seeds of wild and other chestnuts for planting». [13]

Once again, Gould will inform Potemkin on May 27, 1785, summing up a kind of report of his two-week journey «which stretched along the Alma River and Belbek to Sevastopol, from there to Balaklava, Alushta and Yalta»: «From Sevastopol to Balaklava, through the deepest rapids of the seashore, I had, in three days, a most fearful and dangerous road, which can hardly be passed by a person; however, there are also excellent beauties: you see in some places extremely large stones hanging over your head, and threatening to fall with their fall, as if they wanted to turn the passer-by into atoms; in other places, gurgling cascades fall from a height and break on the rocks, watering the beautiful shrubbery. Neither Italy nor any other country can compare with these places, the pleasures of the abundance of water springs and streams... There are, of course, nowhere so many fragrant flowers as here, and there is no great abundance of fish as in these waters, which, like honey and wax, can be exported to the Roman Catholic states». [14]

In the same year, 1785, Gould will visit two more Potemkin estates. So, stopping in Kach, he will notice «a very good garden of young fertile trees, between which other wild trees grow to no small harm; why they need to be destroyed. This garden should be fenced with a good fence. There is a beautiful stream here, on which you can build a mill». Another, located in the vicinity of Sudak, in his opinion, is undoubtedly «the most excellent place for farming... Here, nature has already made a garden that requires only a little help». [15]

With undisguised delight, he will also speak about «the truly picturesque» amazing views of the Crimea: «Some mountain ranges are magnificently decorated with lush trees, some are dressed with sophisticated greenery, and some are burdened with terrible stones». [16]

In another Crimean possession, already located on the Burunche River between Karasubazar and Levkopol, in accordance with the personal order of the prince, Gould in 1787 will be engaged in the construction of another park. According to the gardener, this was not difficult for him and did not require much time: «...without further reasoning, you can do it immediately. Another place in the park is to plant trees and flower beds on the surface of the mountains; then there can be a pleasant garden here». [17] And on May 6, 1787 Potemkin will instruct the gardener to «inspect Baidar and choose a place, the most beautiful, where to place a bet for Her Majesty, to make a garden here, as best as possible, and with water». [18]

Two years later, in the summer of 1789 , Gould would tour a number of G.A. Potemkin's estates in the Mogilev province. It was then that he developed a master plan for the construction of a landscape park in Dubrovna. [19] As it was possible to clarify, shortly before that (in the spring of the same year), the prince lived for some time in this ancient estate, and therefore it is with its complex reconstruction that the very appearance of this idea should be associated.

In the first half of 1789, Gould arrived in Ekaterinoslav (Dnepropetrovsk), which was founded only recently, in 1776, and which was conceived by G.A. Potemkin as one of the three largest cities in Novorossiya. Here, according to the project of I.E. Starov, the prince built his palace, while Gould's business trip assumed the construction of an extensive landscape park with him. It was created on the elevated banks of the Dnieper River and was intended to complete the ensemble of the city center together with the squares and streets converging to the Potemkin Palace - the main urban landmark.

Once again notifying Potemkin about his current affairs, the gardener will emphasize: «Finally, I rushed to Ekaterinoslav! I have already informed you of the plan of Your Grace's choice of the most beautiful place in the world. The position of it contains characters, that are majestic, pleasant, terrible historical, poetic and rural, in short. This place must be the wonder of the whole world! There I had the opportunity to plant using different people different trees up to twenty thousand. What changes I have also made can be witnessed by the Governor». [20]

Delivery of a huge number of seedlings will continue in the autumn of 1789 , when some of them were carried out directly from the Kremenchug state garden. [21] In the open areas, however, mostly expensive exotics were planted, brought from afar. So, from Berlin American maple was brought, from Warsaw - chestnuts, and from Constantinople - mulberries. 
To significantly accelerate the large-scale work on the «English garden», Gould widely used captured Turks, but they were clearly not enough, so V.V. Kakhovsky will order to send them «two hundred more people from local residents». [22]

This very extensive landscape park included the upper-upland and lower parts descending to the Dnieper coastline, and both combined an infinite number of picturesque views and panoramic openings, including the river surface going beyond the horizon. It is no coincidence that these extremely important artistic merits of his will be noted in 1839 by French traveler Hommaire de Hell: «A magnificent park, remarkable for views and prospects, combining copses, mazes, granite rocks covered with rich vegetation, it is arranged with quaint paths, boxes and unexpected views». [23] And the Ekaterinoslav botanist I. A. Akinfiev at the end of the XIX century noticed: «The trees are tall, together with the shrubs along the ravines and irregularities form very dense groves, in which and between which in the clearings in early spring almost all kinds of grasses peculiar to the right bank of the Dnieper are found». [24] Consequently, in addition to the deeply thought-out large-scale planting of trees and shrubs (including fruit trees), as well as the formation of the most active perception of individual parts of the park and its picturesque surroundings, Gould attached fundamental importance to the variety of grass cover that is very characteristic of this area.

Gould's initiative should also be associated with the construction of two very extensive greenhouses in the park - «one pineapple, the other consisted of laurel, orange, lemon, orange, pomegranate, date and other foreign trees; the branches of some trees extended in all directions for several dozen yards». [25]

Consequently, in addition to the impressive figurative and artistic significance, this very extensive park composition created by Gould in a relatively short period of time initially provided for the most active use as a fruit and botanical nursery.

In Vitovka, which was soon renamed Bogoyavlensk (now Nikolaev), G.A. Potemkin will entrust the establishment of shipyards to M.I. Faleev, I.E. Starov will be engaged in drawing up the general plan of the city and designing its development, and he will involve Gould in the formation of his own park. And, accordingly, on August 24, 1798, Potemkin will notify Faleyev: «The English gardener Gould has been sent from me to Vitovka. Show him the place I have designated for my house, between Vitovka and Faberova's dacha, where there is a small wood. He designs how to surround this forest with roads and turn it into a garden, plant flowers, and even more roses. He will also choose a place for grapes, for conservatories, greenhouses and a garden of fruit trees». [26]

Having dealt with the specific situation on the spot, Gould will inform the prince as follows: «Between all my travels, I have not found a more fruitful land here for all growths in general; (...) In this blessed land, I have designated a botanical, grape, vegetable, and fruitful English garden, which is not inferior to any other pleasant and advantageous position. This garden, lying in the bowels of the most pleasant valley, is filled with a clear and softly murmuring spring, having in mind the Bug River, and, being closed from the east and north winds, is satiated with the southern tender air. According to which the most delicate trees can thrive there in perfection. And so that the fruits ripen sooner, then with the slightest dependence, you can build walls and greenhouses from the stone that is in place. (...) From my plan, Your Grace, you can see what can be done between Bogoyavlensky and Favrovoy. The dead plane is very opposed to the planting of the garden, which contains many rotten and smelly bays, which can not be drained because due to the strong winds these bays are always filled again from the Bug River.

From here I went to the spring near Krasnoe Selo, which Your Lordship noticed on the plan, and it is clear that I gave the water a little space, which the position of the land allowed. The place for the house is proud and dominates over many beautiful views, burdened with majestic oaks and other trees». [27]

This is actually the most recent of all the Potemkin parks implemented in the south of Russia, which was of a relatively small size (about $600 \mathrm{~m}$ in length and $250 \mathrm{~m}$ in width). Gould will place it on the terrain between the Bug River and the road to Nikolaev-along the long Wittovsky ravine, at the bottom of which a stream ran. It is thanks to its presence that it will form a whole series of picturesquely curving channels that effectively separated the different parts of the «English garden». [28] The structural connection between them was provided by numerous wooden bridges and a very developed network of landscape paths combined with them. In the space of this park, there were few structures - a manor house, a greenhouse, a greenhouse and a bathhouse. Gould 
also attached particular importance to the multidimensional visual interaction of his park with the surrounding area. In particular, on the right bank of the Vitovskaya Gully, according to his own project, an extensive grape garden will be laid out and a picturesque hut for a viticulturist will be built.

\section{CONCLUSION}

With the death of G.A. Potemkin, Gould's business trips to the southern regions of the country will finally end. As it turns out, the main impulse of this unusually active creative activity of the gardener was initially predetermined by the largescale state interests of his eminent customer, who sought in a relatively short time to bring into clear compliance with the strategic aspirations of the Russian Empire the new vast lands that had gone to it.

Creating numerous garden and park compositions on the outskirts of the state, Gould also demonstrated comprehensive professional training and emphasized efficiency, bold initiative and outstanding artistic skill, stemming from the theory and practice of outstanding representatives of the English horticultural school. Including with his submission, the southern region will receive a powerful impetus for all subsequent multi-vector development of horticulture.

\section{AUTHORS' CONTRIBUTIONS}

This paper is independently completed by Vladimir Chekmarev.

\section{REFERENCES}

[1] Russian state archive of ancient acts (Rossiiskii gosudarstvennyi arkhiv drevnikh aktov), Fund 1239. Inventory 3. Part 111. Case 55254. Report extract of Troshchinsky on the petitions of the Empress Catherine II, 1794 [in Russian].

[2] Russian state archive of ancient acts (Rossiiskii gosudarstvennyi arkhiv drevnikh aktov), Fund 11. Part 2. Case 946. Letters of W. Gould to Prince G.A. Potemkin [in French].

[3] V.V. Antonov, William Gould - the gardener of Prince Potemkin-Tavrichesky (Vil'iam Gul'd - sadovnok kniazia PotemkinaTavricheskogo), in: Nevsky archive: historical and local history collection (Nevskii arkhiv: istoriko-kraevedcheskii sbornik), vol. 4, Chernyshov Publ., St. Petesburg, 1999, pp. 143-166, 148 [in Russian].

[4] Russian state military historical archive (Rossiiskii gosudarstvennyi voennoistoricheskii arkhiv), Fund 52. Part 2. Case 105. Sheet 11. The register of the plans of the estates of the late Serene Prince G.A. Potemkin, which can be sold to the treasury to pay the debts of His Serene Highness» [in Russian].

[5] V.V. Antonov, William Gould - the gardener of Prince Potemkin-Tavrichesky (Vil'iam Gul'd - sadovnok kniazia PotemkinaTavricheskogo), in: Nevsky archive: historical and local history collection (Nevskii arkhiv: istoriko-kraevedcheskii sbornik), vol. 4, Chernyshov Publ., St. Petesburg, 1999, pp. 143-166, 148 [in Russian].

[6] N.F. Gulyanitsky, Petersburg and other new Russian cities of the XVIII-first half of the XIX centuries Peterburg I drugie novye rossiiskie goroda XVIII - pervoi poloviny XIX vv.), Stroiizdat, Moscow, 1995, p. 317 [in Russian].

[7] V.V. Antonov, William Gould - the gardener of Prince Potemkin-Tavrichesky (Vil'iam Gul'd - sadovnok kniazia PotemkinaTavricheskogo), in: Nevsky archive: historical and local history collection (Nevskii arkhiv: istoriko-kraevedcheskii sbornik), vol. 4, Chernyshov Publ., St. Petesburg, 1999, pp. 143-166, 150 [in Russian].

[8] Ibid.

[9] Russian state archive of ancient acts (Rossiiskii gosudarstvennyi arkhiv drevnikh aktov), Fund 11. Part 2. Case 946. Sheet 132. Letter of W. Gould to Prince G.A. Potemkin [in French].

[10] V.V. Antonov, William Gould - the gardener of Prince Potemkin-Tavrichesky (Vil'iam Gul'd - sadovnok kniazia PotemkinaTavricheskogo), in: Nevsky archive: historical and local history collection (Nevskii arkhiv: istoriko-kraevedcheskii sbornik), vol. 4, Chernyshov Publ., St. Petesburg, 1999, pp. 143-166, 154 [in Russian].

[11] A.G. Brickner, Potemkin, Publ. K.L. Rikkera, St. Petersburg, 1891, p. 98 [in Russian]. 
[12] M.N. Kovalensky, The journey of Catherine II to the Crimea (Puteshestvie Ekateriny II v Krym), Mir Partnership Publ. (Tovarishchestvo Mir), Moscow, 1916, p. 87 [in Russian].

[13] V.V. Antonov, William Gould - the gardener of Prince Potemkin-Tavrichesky (Vil'iam Gul'd - sadovnok kniazia PotemkinaTavricheskogo), in: Nevsky archive: historical and local history collection (Nevskii arkhiv: istoriko-kraevedcheskii sbornik), vol. 4, Chernyshov Publ., St. Petesburg, 1999, pp. 143-166, 152 [in Russian].

[14] Letters of the gardener W. Gould to G.A. Potemkin, in: Notes of the Imperial Odessa Society of History and Antiquities (Zapiski Odesskogo obshchestva istorii I drevnostei), vol. IX, Notes Odessa archeological society (Zapiski Odesskogo arkhelogicheskogo obshchestva), Odessa, 1875, pp. 256-257 [in Russian].

[15] Ibid., p. 258.

[16] Ibid.

[17] Letters of the gardener W. Gould to G.A. Potemkin, in: Notes of the Imperial Odessa Society of History and Antiquities (Zapiski Odesskogo obshchestva istorii I drevnostei), vol. X, Notes Odessa archeological society (Zapiski Odesskogo arkhelogicheskogo obshchestva), Odessa, 1877, p. 251 [in Russian].

[18] V.V. Antonov, William Gould - the gardener of Prince Potemkin-Tavrichesky (Vil'iam Gul'd - sadovnok kniazia PotemkinaTavricheskogo), in: Nevsky archive: historical and local history collection (Nevskii arkhiv: istoriko-kraevedcheskii sbornik), vol. 4, Chernyshov, St. Petesburg Publ., 1999, pp. 143-166, 155 [in Russian].

[19] N. Belekhov, A. Petrov, Ivan Starov, Moscow, 1950, p. 169 [in Russian].

[20] Russian state archive of ancient acts (Rossiiskii gosudarstvennyi arkhiv drevnikh aktov), Foundation 11. Inventory 1. Part 2. Case 950, Sheets 231-232 turnover [in Russian].

[21] The chronicle of the Ekaterinoslav Scientific Archival Commission (Letopis' Ekaterinoslavskoi uchenoi arkhivnoi komissii), vol. 10, A. Siniavskii (ed.), Ekaterinoslav, 1915, p. 239 [in Russian].

[22] Kiev antiquity 5-7 (1901) 14 [in Russian].

[23] V.V. Antonov, William Gould - the gardener of Prince Potemkin-Tavrichesky (Vil'iam Gul'd - sadovnok kniazia PotemkinaTavricheskogo), in: Nevsky archive: historical and local history collection (Nevskii arkhiv: istoriko-kraevedcheskii sbornik), vol. 4, Chernyshov Publ., St. Petesburg, 1999, pp. 143-166, 161 [in Russian].

[24] I.Y. Akinfiev, Vegetation of Ekaterinoslav at the end of the first century of its existence (Rastitel'not' Ekaterinoslava v kontse pervogo stoletia ego sushchestvovaniia), N.Ia. Pavloskogo Publ., Ekaterinoslav, 1889, p.29 [in Russian].

[25] K.N. Korolkov, Centenary of the city of Ekaterinoslav (1787 - May 9, 1887) (Stoletnii ubilei goroda Ekaterinoslava (1787 - May 9, 1887), N.Ia. Pavloskogo Publ., Ekaterinoslav, 1887, p. 14 [in Russian].

[26] To name-the city of Nikolaev. Historical and local history issue, Nikolaev, 1989, p. 178 [in Russian].

[27] Russian state archive of ancient acts (Rossiiskii gosudarstvennyi arkhiv drevnikh aktov), Foundation 11. Inventory 1. Part 2. Case 950, Sheets 231-232 turnover [in Russian].

[28] N.A. Kukhar-Onyshko, Bogoiavlensk - the cradle of Nikolaev (Bogoiavlensk - kolybel' Nikolaeva), Iriny Gudym, Nikolaev Publ., 2013, p. 92 [in Russian]. 